\title{
Perilaku Masyarakat dan Masalah Pelayanan Kesehatan Ibu dan Anak di Provinsi Riau
}

\author{
Community Behavior and Health Care of Maternal and Child Health \\ Problems in Province of Riau
}

\section{Zahtamal, Tuti Restuastuti, Fifia Chandra}

Bagian Ilmu Kesehatan Masyarakat Kedokteran Komunitas Fakultas Kedokteran Universitas Riau

\begin{abstract}
Abstrak
Status kesehatan masyarakat yang rendah di Indonesia ditandai oleh angka kematian ibu dan angka kematian bayi yang tinggi sebagaimana terlihat pada indikator pelayanan KIA yang belum ideal. Penelitian ini bertujuan untuk mengetahui situasi pelayanan KIA dan mengkaji faktor perilaku sebagai penyebab masalah KIA di Provinsi Riau. Riset ini menggunakan rancangan studi deskriptif dengan data kuantitatif dan kualitatif mengenai indikator keberhasilan pelayanan KIA. Hasil penelitian ini menunjukkan bahwa indikator-indikator kinerja pelayanan KIA ada yang tercapai, ada pula yang tidak. Sementara itu, perilaku masyarakat terhadap pengetahuan tentang kehamilan ibu tergolong baik, sikap netral, dan praktek baik. Seseorang yang berpengaruh besar terhadap pengambilan keputusan dalam upaya tindakan kesehatan sebagian besar menyatakan suami/istri. Jika dilihat dari aspek kecepattanggapan keluarga dalam merespon anggota keluarga yang mempunyai masalah KIA, sebagian besar tidak ada keterlambatan. Masih banyak kepercayaan masyarakat yang belum sesuai dengan nilai-nilai kesehatan, terutama terhadap aspek KIA.

Kata kunci: Pelayanan kesehatan, kesehatan ibu dan anak, perilaku masyarakat

Abstract

Low health community status in Indonesia is indicated by high maternal and infant mortality rates as shown in the indicators of health care of maternal and child health not ideal. The aim of this study was to understand the situation of maternal and child health and to analyze behavioral factor determining maternal and child health problems in Riau Province. This research employed descriptive design with quantitative and qualitative data on achievement of performance indicators of maternal and child health. The results showed that some performance indicators of maternal and child health were achievable and some were not. Meanwhile, the community health behavior about maternal health knowledge was good, attitude was neutral, and practice was good. Similarly, the community health behavior about new-
\end{abstract}

born and child health level of knowledge was medium, attitude was positive, and practice was good. In solving maternal and child health problems, key person who mostly categorized as a decision maker for health action was husband or wife. With respect to the family emergency response to maternal and child health problems of a family member, most decisions to care the problems were not late. However, there were many communities' beliefs which do not match the health values, especially for maternal and child health aspects.

Key words: Health care, maternal and child health, community behaviour

\section{Pendahuluan}

Saat ini, masalah kesehatan di Indonesia yang rendah antara lain ditandai oleh angka kematian ibu (AKI) dan angka kematian bayi (AKB) yang tinggi. Berdasarkan survei kesehatan dasar 2007, AKI di Indonesia masih tergolong tinggi (228 per 100.000 kelahiran hidup). Demikian pula AKB, masih berada pada kisaran 26,9 per 1.000 kelahiran hidup. Departemen Kesehatan Republik Indonesia menyatakan target AKI dan AKB yang diharapkan dicapai pada tahun 2010 adalah 125 per 100.000 kelahiran hidup dan 15 per 1.000 kelahiran hidup. ${ }^{1}$ Berdasarkan data Dinas Kesehatan Provinsi Riau, diketahui bahwa angka kematian bayi 26 per 1000 kelahiran hidup dan angka kematian anak balita 60 per 1000 kelahiran hidup. Jumlah kematian bayi mencapai 1.272 kasus, sedangkan jumlah kematian ibu mencapai 179 kasus pada tahun $2006 .^{2}$

AKI dan AKB yang masih tergolong tinggi tersebut

Alamat Korespondensi: Zahtamal, Bagian Ilmu Kesehatan Masyarakat Kedokteran Komunitas FK Universitas Riau Jl. Diponegoro No. 1 Pekanbaru, Hp.081371530203,e-mail:ta_mal75@yahoo.co.id 
disebabkan oleh berbagai faktor yang meliputi faktor penyedia (predisposing), faktor pemungkin (enabling) serta faktor pendorong atau penguat (reinforcing). Faktor-faktor tersebut berupa berbagai hambatan aspek geografis, ekonomi, sosiokultural, yang diperberat oleh kelemahan dalam mendeteksi, memutuskan tindakan serta merujuk. Selain itu, akibat keterlambatan menangani keluarga yang mempunyai masalah kesehatan di fasilitas pelayanan kesehatan komperehensif. Belum banyak informasi yang menggambarkan berbagai faktor tersebut, khususnya dari aspek perilaku masyarakat. Padahal, strategi dan kebijakan tepat yang dikembangkan berdasarkan informasi bukti sangat diperlukan dalam upaya mengatasi masalah KIA tersebut. Tujuan penelitian ini adalah memperoleh gambaran berbagai indikator dan faktor perilaku yang terkait pelayanan KIA di masyarakat.

\section{Metode}

Penelitian ini menggunakan desain deskriptif dengan data kuantitatif dan kualitatif yang dilakukan di 4 kabupaten/kota di Provinsi Riau dengan karakteristik masyarakat nelayan/pesisir, pertanian dan perkebunan serta perkotaan industri. Untuk merepresentasikan karakteristik tersebut dipilih masyarakat yang bermukim di Kota Pekanbaru mewakili wilayah perkotaan, Kabupaten Kampar mewakili daerah perkebunan/pertanian, Kota Dumai mewakili daerah industri, dan Kabupaten Rokan Hilir mewakili daerah nelayan/pesisir. Penelitian yang dilakukan pada tahun 2009 mengamati masyarakat di lokasi penelitian terpilih. Jumlah wilayah studi dan responden ditentukan secara quota sampling. Besar sampel ditentukan 550 orang masyarakat, masingmasing setiap kabupaten/kota berada pada kisaran 120150 orang. Instrumen yang digunakan adalah format identifikasi indikator pelayanan kesehatan dari data sekunder dan kuesioner.

\section{Hasil}

Secara umum, indikator keberhasilan pembangunan kesehatan untuk pelayanan KIA antara lain adalah AKI, jumlah anak balita bawah garis merah (BGM) (kurang $15 \%)$. Beberapa indikator lain yaitu cakupan balita yang naik berat badan (ada 2 kabupaten yang belum mencapai target yakni Kampar dan Rokan Hilir) dan cakupan Posyandu Purnama (ada 1 kabupaten yang belum mencapai target yakni Rokan Hilir). Selanjutnya, cakupan kunjungan bayi (ada 2 kabupaten yang belum mencapai target yakni Kampar dan Rokan Hilir). Indikator yang belum mencapai target antara lain cakupan kunjungan ibu hamil (K4), pertolongan persalinan ditolong petugas kesehatan, kunjungan neonatus (KN-2), cakupan peserta keluarga berencana (KB) aktif, cakupan desa/kelurahan kategori universal child immunization (UCI), caku- pan anak balita yang mendapat kapsul vitamin A 2 kali setahun, cakupan ibu hamil yang mendapat 90 tablet fe, cakupan pemberian makanan pendamping air susu ibu (MP-ASI) pada anak balita bawah garis merah dari keluarga miskin, cakupan rumah tangga sehat serta cakupan bayi yang mendapat ASI ekslusif.

\section{Faktor Perilaku terkait Pelayanan KIA}

Jumlah responden dalam penelitian ini adalah 550 orang dengan rata-rata umur 29,63 tahun (standar deviasi $(\mathrm{SD})=5,82)$. Status ekonomi responden sebagian besar berpenghasilan Rp. 800.000-2.000.000 (menengah rendah) yakni $61,3 \%$. Selanjutnya, jika dilihat dari cara pembayaran untuk mendapatkan pelayanan kesehatan yang sering digunakan keluarga adalah bayar langsung yakni 397 orang $(72,2 \%)$. Hanya $20,1 \%$ yang ditanggung oleh asuransi (Asuransi Kesehatan (Askes)/Jaminan Sosial Tenaga Kerja (Jamsostek), Askes swasta, dan Jaminan Kesehatan Masyarakat (Jamkesmas)). Tenaga penolong dalam pemenuhan kebutuhan pelayanan kesehatan keluarga sebagian besar adalah tenaga kesehatan (dokter/perawat/bidan/mantri kesehatan) yakni 542 orang $(98,5 \%)$. Sarana/fasilitas kesehatan yang paling sering digunakan oleh keluarga sebagian besar responden menjawab adalah puskesmas yakni 266 orang $(48,4 \%)$.

\section{Pengetahuan tentang Kehamilan, Persalinan, dan Nifas}

Gambaran rata-rata skor pengetahuan responden tentang kehamilan, persalinan, dan nifas adalah 74,05 (SD $=14,51$ ). Secara keseluruhan, diketahui kategori pengetahuan responden berada pada kategori baik yakni 366 orang $(66,6 \%)$ (Lihat Tabel 1). Jumlah yang paling banyak kategori baiknya adalah Kota Dumai (86,2\%), sedangkan yang terendah adalah Kabupaten Rokan Hilir $(50,7 \%)$. Berdasarkan uji komparatif kategorik diketahui bahwa terdapat perbedaan yang bermakna pengetahuan responden dengan nilai signifikan ( $p$ value $=0,000$ ).

\section{Pengetahuan tentang Kesehatan Bayi}

Berdasarkan pengolahan data didapatkan rata-rata skor pengetahuan responden tentang kesehatan bayi adalah 63,87 $(\mathrm{SD}=19,01)$. Secara keseluruhan diketahui bahwa kategori pengetahuan responden berada pada kategori cukup yakni 283 orang $(51,5 \%)$ (Lihat Tabel 2).

Berdasarkan Tabel 2 diketahui bahwa kategori pengetahuan responden sedikit bervariasi, 3 kabupaten/kota sebagian besar dengan kategori cukup (Rokan Hilir, Dumai, dan Kampar), sedangkan Pekanbaru sebagian besar $(60,3 \%)$ berada pada kategori baik. Selanjutnya, kabupaten yang kurang ideal kategori pengetahuannya adalah Rokan Hilir, dimana kategori cukup dan kurangnya masih banyak yakni masing- 
Tabel 1. Pengetahuan Responden tentang Kehamilan, Persalinan, dan Nifas

\begin{tabular}{|c|c|c|c|c|c|c|}
\hline \multirow{2}{*}{\multicolumn{2}{|c|}{ Kategori Pengetahuan }} & \multicolumn{4}{|c|}{ Kabupaten } & \multirow{2}{*}{ Total } \\
\hline & & Rokan Hilir & Dumai & Pekanbaru & Kampar & \\
\hline \multirow[t]{3}{*}{ Kurang } & Jumlah & 3 & 0 & 0 & 2 & 5 \\
\hline & Nilai expected & 1,3 & 1,3 & 1,1 & 1,4 & 5,0 \\
\hline & $\%$ kabupaten & $2,1 \%$ & $0 \%$ & $0 \%$ & $1,3 \%$ & $0,9 \%$ \\
\hline \multirow{3}{*}{ Cukup } & Jumlah & 67 & 19 & 28 & 65 & 179 \\
\hline & Nilai expected & 46,2 & 44,9 & 37,8 & 50,1 & 179,0 \\
\hline & $\%$ kabupaten & $47,2 \%$ & $13,8 \%$ & $24,1 \%$ & $42,2 \%$ & $32,5 \%$ \\
\hline \multirow[t]{3}{*}{ Baik } & Jumlah & 72 & 119 & 88 & 87 & 366 \\
\hline & Nilai expected & 94,5 & 91,8 & 77,2 & 102,5 & 366,0 \\
\hline & $\%$ kabupaten & $50,7 \%$ & $86,2 \%$ & $75,9 \%$ & $56,5 \%$ & $66,5 \%$ \\
\hline \multirow[t]{3}{*}{ Total } & Jumlah & 142 & 138 & 116 & 154 & 550 \\
\hline & Nilai expected & 142,0 & 138,0 & 116,0 & 154,0 & 550,0 \\
\hline & $\%$ kabupaten & $100 \%$ & $100 \%$ & $100 \%$ & $100 \%$ & $100 \%$ \\
\hline
\end{tabular}

Tabel 2. Pengetahuan Kesehatan Bayi

\begin{tabular}{|c|c|c|c|c|c|c|}
\hline \multirow{2}{*}{\multicolumn{2}{|c|}{ Kategori Pengetahuan }} & \multicolumn{4}{|c|}{ Kabupaten } & \multirow{2}{*}{ Total } \\
\hline & & Rokan Hilir & Dumai & Pekanbaru & Kampar & \\
\hline \multirow[t]{3}{*}{ Kurang } & Jumlah & 15 & 5 & 3 & 4 & 27 \\
\hline & Nilai expected & 7,0 & 6,8 & 5,7 & 7,6 & 27,0 \\
\hline & $\%$ kabupaten & $10,6 \%$ & $3,6 \%$ & $2,6 \%$ & $2,6 \%$ & $4,9 \%$ \\
\hline \multirow[t]{3}{*}{ Cukup } & Jumlah & 69 & 86 & 43 & 85 & 283 \\
\hline & Nilai expected & 73,1 & 71,0 & 59,7 & 79,2 & 283,0 \\
\hline & $\%$ kabupaten & $48,6 \%$ & $62,3 \%$ & $37,1 \%$ & $55,2 \%$ & $51,5 \%$ \\
\hline \multirow[t]{3}{*}{ Baik } & Jumlah & 58 & 47 & 70 & 65 & 240 \\
\hline & Nilai expected & 62,0 & 60,2 & 50,6 & 67,2 & 240,0 \\
\hline & $\%$ kabupaten & $40,8 \%$ & $34,1 \%$ & $60,3 \%$ & $42,2 \%$ & $43,6 \%$ \\
\hline \multirow[t]{3}{*}{ Total } & Jumlah & 142 & 138 & 116 & 154 & 550 \\
\hline & Nilai expected & 142,0 & 138,0 & 116,0 & 154,0 & 550,0 \\
\hline & $\%$ kabupaten & $100 \%$ & $100 \%$ & $100 \%$ & $100 \%$ & $100 \%$ \\
\hline
\end{tabular}

masing $48,6 \%$ dan 10,6\%. Melalui uji chi square diketahui bahwa terdapat perbedaan yang bermakna pengetahuan antarkabupaten/kota dengan nilai signifikan ( $p$ value $=0,000$ ).

\section{Gambaran Sikap Responden terhadap Kehamilan, Persalinan, dan Nifas}

Secara keseluruhan diketahui bahwa rata-rata skor sikap responden terhadap kehamilan, persalinan, dan nifas adalah 69,92 $(\mathrm{SD}=11,59)$. Adapun kategori sikap responden sebagian besar berada pada kategori netral yakni 137 responden $(93,8 \%)$ (Lihat Tabel 3).

Berdasarkan Tabel 3 diketahui bahwa kategori sikap responden sedikit bervariasi, dimana 3 kabupaten sebagian besar dengan kategori positif (Dumai, Pekanbaru, dan Kampar), sedangkan Rokan Hilir sebagian besar adalah netral yakni sebanyak 52,1\%. Melalui uji chi squ- are diketahui bahwa terdapat perbedaan yang bermakna kategori sikap antar kabupaten/kota dengan nilai signifikan $(p$ value $=0,001)$.

\section{Gambaran Sikap Responden terhadap Kesehatan Bayi}

Secara keseluruhan diketahui bahwa rata-rata skor sikap responden terhadap kesehatan bayi adalah 75,47 $(\mathrm{SD}=15,06)$. Adapun kategori sikap responden sebagian besar sudah berada pada kategori positif yakni 362 responden $(65,8 \%)$ (Lihat Tabel 4$)$.

Berdasarkan Tabel 4 diketahui bahwa kategori sikap responden sedikit bervariasi, dimana 3 kabupaten/kota sebagian besar dengan kategori positif (Dumai, Pekanbaru, dan Kampar), sedangkan Rokan Hilir sebagian besar adalah netral yakni sebanyak 52,1\%. Melalui analisis statistik dengan uji komparatif kategorik tidak berpasangan diketahui bahwa terdapat perbedaan yang 
Tabel 3. Sikap Responden terhadap Kehamilan, Persalinan, dan Nifas

\begin{tabular}{|c|c|c|c|c|c|c|}
\hline \multirow{2}{*}{\multicolumn{2}{|c|}{ Kategori Sikap }} & \multicolumn{4}{|c|}{ Kabupaten } & \multirow{2}{*}{ Total } \\
\hline & & \multirow{2}{*}{$\begin{array}{c}\text { Rokan Hilir } \\
74\end{array}$} & \multirow{2}{*}{$\begin{array}{l}\text { Dumai } \\
59\end{array}$} & \multirow{2}{*}{$\begin{array}{c}\text { Pekanbaru } \\
31\end{array}$} & \multirow{2}{*}{$\begin{array}{c}\text { Kampar } \\
60\end{array}$} & \\
\hline Netral & Jumlah & & & & & 224 \\
\hline & Nilai expected & 57,8 & 56,2 & 47,2 & 62,7 & 224,0 \\
\hline & $\%$ kabupaten & $52,1 \%$ & $42,8 \%$ & $26,7 \%$ & $39,0 \%$ & $40,7 \%$ \\
\hline \multirow[t]{3}{*}{ Positif } & Jumlah & 68 & 79 & 85 & 94 & 326 \\
\hline & Nilai expected & 84,2 & 81,8 & 68,8 & 91,3 & 326,0 \\
\hline & $\%$ kabupaten & $47,9 \%$ & $57,2 \%$ & $73,3 \%$ & $61,0 \%$ & $59,3 \%$ \\
\hline \multirow[t]{3}{*}{ Total } & Jumlah & 142 & 138 & 116 & 154 & 550 \\
\hline & Nilai expected & 142,0 & 138,0 & 116,0 & 154,0 & 550,0 \\
\hline & $\%$ kabupaten & $100 \%$ & $100 \%$ & $100 \%$ & $100 \%$ & $100 \%$ \\
\hline
\end{tabular}

Tabel 4. Sikap Responden terhadap Kesehatan Bayi

\begin{tabular}{|c|c|c|c|c|c|c|}
\hline \multirow{2}{*}{\multicolumn{2}{|c|}{ Kategori Sikap }} & \multicolumn{4}{|c|}{ Kabupaten } & \multirow{2}{*}{ Total } \\
\hline & & Rokan Hilir & Dumai & Pekanbaru & Kampar & \\
\hline \multirow[t]{3}{*}{ Negatif } & Jumlah & 5 & 0 & 0 & 0 & 5 \\
\hline & Nilai expected & 1,3 & 1,3 & 1,1 & 1,4 & 5,0 \\
\hline & $\%$ kabupaten & $3,5 \%$ & $0 \%$ & $0 \%$ & $0 \%$ & $0,9 \%$ \\
\hline \multirow[t]{3}{*}{ Netral } & Jumlah & 65 & 47 & 19 & 52 & 183 \\
\hline & Nilai expected & 47,2 & 45,9 & 38,6 & 51,2 & 183,0 \\
\hline & $\%$ kabupaten & $45,8 \%$ & $34,1 \%$ & $16,4 \%$ & $33,8 \%$ & $33,3 \%$ \\
\hline \multirow[t]{3}{*}{ Positif } & Jumlah & 72 & 91 & 97 & 102 & 362 \\
\hline & Nilai expected & 93,5 & 90,8 & 76,3 & 101,4 & 362,0 \\
\hline & $\%$ kabupaten & $50,7 \%$ & $65,9 \%$ & $83,6 \%$ & $66,2 \%$ & $65,8 \%$ \\
\hline \multirow[t]{3}{*}{ Total } & Jumlah & 142 & 138 & 116 & 154 & 550 \\
\hline & Nilai expected & 142,0 & 138,0 & 116,0 & 154,0 & 550,0 \\
\hline & $\%$ kabupaten & $100 \%$ & $100 \%$ & $100 \%$ & $100 \%$ & $100 \%$ \\
\hline
\end{tabular}

bermakna kategori sikap antar kabupaten/kota dengan nilai signifikan ( $p$ value $=0,000)$.

\section{Praktek Pemeliharaan Kesehatan Ibu Hamil, Ibu Bersalin,} dan Ibu Nifas

Secara keseluruhan diketahui bahwa rata-rata skor praktek responden untuk peningkatan dan pemeliharaan kesehatan ibu hamil, ibu bersalin, dan ibu nifas adalah $80,70(\mathrm{SD}=8,03)$. Adapun kategori praktek responden sebagian besar berada pada kategori baik yakni sebanyak 329 responden $(59,8 \%)$ (Lihat Tabel 5).

Berdasarkan Tabel 5 diketahui bahwa kategori praktek responden sedikit bervariasi, dimana 3 kabupaten sebagian besar dengan kategori baik (Dumai, Pekanbaru, dan Kampar), sedangkan Rokan Hilir sebagian besar berada pada kategori kurang yakni sebanyak $60,6 \%$. Melalui uji chi square diketahui bahwa terdapat perbedaan yang bermakna kategori praktek antar kabupaten/kota dengan nilai signifikan ( $p$ value $=0,000$ ).
Praktek Upaya Peningkatan Kesehatan pada Bayi dan Anak Balita

Rata-rata skor praktek upaya peningkatan kesehatan pada bayi dan anak balita adalah 84,89 $(\mathrm{SD}=17,19)$. Adapun kategori praktek responden sebagian besar berada pada kategori baik yakni sebanyak 446 responden $(81,1 \%)$ (Lihat Tabel 6).

Berdasarkan Tabel 6 diketahui bahwa kategori praktek responden antarkabupaten/kota adalah sama, dimana 4 kabupaten/kota sebagian besar dengan kategori baik. Akan tetapi, Kabupaten Rokan Hilir memiliki kategori kurang masih cukup banyak yakni sebanyak $36,6 \%$. Kabupaten/kota yang sangat baik praktek untuk peningkatan kesehatan pada bayi dan anak balita adalah Kota Pekanbaru dengan kategori baik sebanyak 95,7\%. Melalui uji chi square diketahui bahwa terdapat perbedaan yang bermakna kategori praktek antarkabupaten/kota dengan nilai signifikan ( $p$ value $=$ $0,000)$ 
Tabel 5. Praktek Pemeliharaan Kesehatan Ibu Hamil, Ibu Bersalin, dan Ibu Nifas

\begin{tabular}{|c|c|c|c|c|c|c|}
\hline \multirow{2}{*}{\multicolumn{2}{|c|}{ Kategori Praktek }} & \multicolumn{4}{|c|}{ Kabupaten } & \multirow{2}{*}{ Total } \\
\hline & & \multirow{2}{*}{$\begin{array}{c}\text { Rokan Hilir } \\
86\end{array}$} & \multirow{2}{*}{$\begin{array}{c}\text { Dumai } \\
61\end{array}$} & \multirow{2}{*}{$\begin{array}{c}\text { Pekanbaru } \\
28\end{array}$} & \multirow{2}{*}{$\begin{array}{c}\text { Kampar } \\
46\end{array}$} & \\
\hline Kurang & Jumlah & & & & & 221 \\
\hline & Nilai expected & 57,1 & 55,5 & 46,6 & 61,9 & 221,0 \\
\hline & $\%$ kabupaten & $60,6 \%$ & $44,2 \%$ & $24,1 \%$ & $29,9 \%$ & $40,2 \%$ \\
\hline \multirow[t]{3}{*}{ Baik } & Jumlah & 56 & 77 & 88 & 108 & 329 \\
\hline & Nilai expected & 84,9 & 82,5 & 69,4 & 92,1 & 329,0 \\
\hline & $\%$ kabupaten & $39,4 \%$ & $55,8 \%$ & $75,9 \%$ & $70,1 \%$ & $59,8 \%$ \\
\hline \multirow[t]{3}{*}{ Total } & Jumlah & 142 & 138 & 116 & 154 & 550 \\
\hline & Nilai expected & 142,0 & 138,0 & 116,0 & 154,0 & 550,0 \\
\hline & $\%$ kabupaten & $100 \%$ & $100 \%$ & $100 \%$ & $100 \%$ & $100 \%$ \\
\hline
\end{tabular}

Tabel 6. Praktek Peningkatan Kesehatan pada Bayi dan Anak Balita

\begin{tabular}{|c|c|c|c|c|c|c|}
\hline \multirow{2}{*}{\multicolumn{2}{|c|}{ Kategori Praktek }} & \multicolumn{4}{|c|}{ Kabupaten } & \multirow{2}{*}{ Total } \\
\hline & & Rokan Hilir & Dumai & Pekanbaru & Kampar & \\
\hline \multirow[t]{3}{*}{ Kurang } & Jumlah & 52 & 20 & 5 & 27 & 104 \\
\hline & Nilai expected & 26,9 & 26,1 & 21,9 & 29,1 & 104,0 \\
\hline & $\%$ kabupaten & $36,6 \%$ & $14,5 \%$ & $4,3 \%$ & $17,5 \%$ & $18,9 \%$ \\
\hline \multirow[t]{3}{*}{ Baik } & Jumlah & 90 & 118 & 111 & 127 & 446 \\
\hline & Nilai expected & 115,1 & 111,9 & 94,1 & 124,9 & 446,0 \\
\hline & $\%$ kabupaten & $63,4 \%$ & $85,5 \%$ & $95,7 \%$ & $82,5 \%$ & $81,1 \%$ \\
\hline \multirow[t]{3}{*}{ Total } & Jumlah & 142 & 138 & 116 & 154 & 550 \\
\hline & Nilai expected & 142,0 & 138,0 & 116,0 & 154,0 & 550,0 \\
\hline & $\%$ kabupaten & $100 \%$ & $100 \%$ & $100 \%$ & $100 \%$ & $100 \%$ \\
\hline
\end{tabular}

\section{Faktor Sosiokultural}

Kategori orang kunci yang berpengaruh besar terhadap pengambilan keputusan dalam upaya tindakan kesehatan sebagian besar adalah suami/istri yakni sebanyak 513 responden $(93,3 \%)$. Selanjutnya, dari aspek kecepattanggapan keluarga dalam merespon anggota keluarga yang sakit (bermasalah) terutama terhadap KIA sebagian besar (458 orang; 83,3\%) menjawab tidak ada keterlambatan dalam memutuskan upaya tindakan kesehatan. Jika dilihat berdasarkan kabupaten/kota diketahui bahwa responden masih banyak juga yang mengatakan "ya/terlambat" yakni Kota Pekanbaru $(20,7 \%)$ dan Rokan Hilir (20,4\%). Khususnya untuk kecepattanggapan keluarga dalam merespon anggota keluarga, aspek keterlambatan dalam memutuskan upaya tindakan untuk ibu yang mau bersalin sebagian besar (495 orang; 90,0\%) menjawab tidak. Berdasarkan kabupaten/kota diketahui bahwa responden masih banyak yang mengatakan "ya/terlambat" yakni Rokan Hilir (15,5\%) dan Kota Pekanbaru (12,1\%).

Berdasarkan pengolahan data diketahui bahwa masih banyak kepercayaan masyarakat yang belum sesuai dengan nilai-nilai kesehatan, terutama terhadap aspek KIA. Sebanyak 274 responden yang menjawab pernyataan kebiasaan/tradisi yang diterapkan/dipercayai dalam kesehariannya yang berhubungan dengan kesehatan ibu hamil/bersalin/nifas/menyusui didapatkan bahwa 124 $(45,26 \%)$ memiliki kepercayaan yang tidak sesuai dengan nilai-nilai kesehatan. Adapun jenis kepercayaan yang keliru/tidak sesuai tersebut sebagian besar terkait aspek gizi selama hamil/bersalin/nifas dan menyusui yakni $31,32 \%$. Kepercayaan yang keliru tersebut misalnya selama bersalin tidak boleh memakan udang dan selama menyusui tidak boleh makan kerang. Ada juga yang mempercayai bahwa selama nifas tidak boleh minum air putih, makan ikan, dan buah-buahan. Selain itu, ada juga aspek kepercayaan yang keliru ketika hamil $(29,52 \%)$. Contoh kepercayaan yang keliru tersebut antara lain urut (kusuk) ibu ketika hamil ke dukun. Jika dilihat per kabupaten/kota, responden yang memiliki kepercayaan yang belum sesuai tersebut yaitu Kabupaten Rokan Hilir $(64,47 \%)$, Kabupaten Kampar $(46,55 \%)$, Kota 
Pekanbaru (38,70\%), dan Kota Dumai (30,77\%). Aspek kepercayaan yang keliru tersebut sebagian besar juga terkait aspek gizi selama hamil/bersalin/nifas dan menyusui.

Selanjutnya, dari 254 orang yang menjawab pernyataan kebiasaan/tradisi yang diterapkan/dipercayai dalam keseharian responden yang berhubungan dengan kesehatan bayi dan anak balita didapatkan bahwa ada 60 $(23,62 \%)$ memiliki kepercayaan yang tidak sesuai dengan nilai-nilai kesehatan. Adapun jenis kepercayaan yang tidak sesuai tersebut sebagian besar terkait aspek gizi pada bayi dan balita atau tidak mendukung ASI eksklusif yakni $42,62 \%$. Kepercayaan tersebut misalnya adalah bayi baru lahir diberi kelapa muda, setiap bayi baru lahir diberi makan pisang. Selain itu, aspek kepercayaan yang keliru terhadap penanganan kesehatan pada bayi dan anak balita $(27,87 \%)$. Contoh kepercayaan yang keliru tersebut antara lain kepercayaan ke dukun, mereka diberi "tetomeh" yaitu sejenis ramuan yang dipercaya dapat menyembuhkan penyakit/mengusir roh jahat penyebab penyakit.

\section{Pembahasan}

Dilihat dari 14 indikator yang dinilai, terlihat hanya 4 indikator $(28,7 \%)$ yang sudah mencapai target. Pembangunan kesehatan atau pelayanan kesehatan yang harus diberikan kepada masyarakat belum maksimal. Sulit mencapai derajat kesehatan yang optimal. Pembangunan kesehatan di Provinsi Riau selama 2 tahun terakhir belum menunjukkan perubahan terhadap indikator standar pelayanan minimal (SPM) yang signifikan. ${ }^{3}$ Hasil ini juga tidak jauh berbeda dengan beberapa kabupaten/kota di Indonesia. Indikator SPM bidang kesehatan di Kabupaten Polewali Mandar Sulawesi yang cakupan antenatal care (ANC) K4 (72,3\%) masih kurang dari target nasional. ${ }^{4}$ Kabupaten Ngawi pada tahun 2008 mencapai target Posyandu Purnama hanya 286 $(24,57 \%)$. Selain itu, cakupan pelayanan K4 hanya $13.218(94,49 \%)$. Beberapa indikator untuk kesehatan bayi dan anak balita seperti cakupan pemberian kapsul vitamin A 2 kali pada balita pada tahun 2008 hanya sebanyak $35.268(78,00 \%) .{ }^{5}$ Pengetahuan tentang kesehatan maternal tergolong baik yakni 366 orang $(66,6 \%)$. Pengetahuan baik merupakan modal awal praktek yang baik dan pada akhirnya terjadi penurunan masalah maternal atau peningkatan indikator pelayanan kesehatan di masyarakat. ${ }^{6}$

Pengetahuan responden tentang kesehatan bayi dan anak balita tergolong cukup. Hal tersebut merupakan sesuatu yang belum ideal yang akan berdampak terhadap upaya modifikasi perilaku oleh pihak terkait yang meliputi pembentukan perilaku baru, peningkatan perilaku maupun pertahanan perilaku. Pengetahuan yang belum ideal merupakan salah satu penyebab peningkatan kasus/permasalahan kesehatan di masyarakat. Seseorang yang belum memiliki pengetahuan yang baik akan mengalami kesulitan mengubah perilaku ke arah positif atau menerima perilaku yang lebih baik. Sebaliknya, orang yang telah berpengetahuan cukup akan menerima atau mengadopsi perilaku baru dengan baik. ${ }^{6}$

Kategori sikap responden terhadap kesehatan ibu maternal sebagian besar adalah netral yang dinyatakan belum ideal karena setiap waktu dapat berubah ke arah positif atau negatif. Faktor yang membentuk sikap dan hubungannya dengan objek-objek tertentu dalam interaksi sosial saling mempengaruhi perilaku individu sebagai anggota masyarakat. Individu bereaksi membentuk sikap tertentu terhadap objek psikologis yang dihadapinya. Stimulasi positif yang kurang menyebabkan hanya sebagian kecil orang yang berpengetahuan tentang objek tertentu. Rangsangan positif yang kurang juga berpengaruh terhadap pertahanan kondisi sikap netral yang dapat menjadi sikap negatif. ${ }^{7}$

Praktek responden terhadap kesehatan maternal sebagian besar tergolong baik. Walaupun lebih dari 50\% baik, tetapi angka ini belum ideal karena ada sebanyak $40,2 \%$ responden belum melakukan upaya yang mendukung kesehatan maternal. Banyak faktor yang terkait mengapa masyarakat belum melakukan praktek kesehatan dengan baik. Faktor tersebut antara adalah predisposing factors, enabling factors, dan reinforcing factors. ${ }^{5}$ Orang dengan tingkat penghasilan yang belum ideal cenderung memperlihatkan praktek yang kurang. Semua responden yang berpengetahuan kurang, sebagian besar berasal dari kelompok yang berpenghasilan Rp. 800.0002.000.000.

Masyarakat yang belum tercakup asuransi (askes/asuransi swasta/Jamsostek/Jamkesmas), umumnya memperlihatkan praktek yang kurang. Masyarakat miskin (penghasilan $<$ Rp. 800.000 per bulan) umumnya sudah tercakup asuransi (terutama Jamkesmas) dan sebagian besar berpraktek dengan kategori baik (65,4\%). Masyarakat ekonomi menengah atas dan ekonomi baik cenderung berpraktek secara baik. Bertentangan dengan masyarakat berpenghasilan menengah bawah, mereka umumnya belum tercakup asuransi $(81,1 \%)$, sebagian besar $(66,5 \%)$ dengan kategori praktek kurang. Diharapkan pemerintah tidak hanya berkonsentrasi menjamin pembiayaan kesehatan masyarakat miskin. Mereka yang berpenghasilan menengah keatas tidak mendapat jaminan pembiayaan kesehatan subsidi pemerintah, hendaknya ditanamkan supaya ikut dalam asuransi kesehatan secara mandiri termasuk menghidupkan kembali dana sehat, terutama kelompok yang berpenghasilan menengah hingga rendah.

Praktek peningkatan kesehatan bayi dan anak balita sebagian besar berada pada kategori baik. Sebagian besar responden yang tidak memberikan ASI jolong untuk bayi 
mengindikasikan pengetahuan tentang ASI yang tergolong kurang. Penelitian lain menemukan mereka tidak tahu melakukan dan mereka tahu tetapi tidak melakukan termasuk peran petugas kesehatan. Terkait dengan ASI eksklusif, ditemukan bahwa bidan menyatakan setuju memberikan susu formula kepada bayi baru lahir. Sebagian ibu dianjurkan petugas kesehatan untuk memberi susu formula pada minggu pertama setelah kelahiran. ${ }^{8}$

Orang kunci yang berpengaruh besar pada pengambilan keputusan tindakan kesehatan sebagian besar adalah suami/istri. Hasil yang sama terlihat pada penelitian di Nusa Tenggara Timur, pengambil keputusan untuk mencari pertolongan persalinan adalah istri $(36,7 \%)$, suami $(30,7 \%)$, orang tua/mertua $(16,9 \%)$, diputuskan secara bersama (suami istri atau anak dan orang tua) $(16,9 \%)$, dan lainnya $(0,9 \%) .{ }^{9}$

Berdasarkan aspek cepat tanggap keluarga merespons anggota keluarga yang sakit, sebagian besar merasa tidak ada keterlambatan memutuskan upaya tindakan kesehatan. Cepat tanggap keluarga merespons tindakan untuk ibu bersalin, umumnya responden menjawab tidak. Dilihat berdasarkan kabupaten/kota diketahui bahwa responden Kota Pekanbaru masih banyak yang mengatakan "terlambat". Hal ini mungkin disebabkan oleh masyarakat yang berusaha mengobati sendiri berdasarkan pengetahuan mereka. Selain itu karena banyak tersedia toko obat/apotek di Kota Pekanbaru.

Masih banyak kepercayaan masyarakat yang belum sesuai dengan nilai-nilai kesehatan, terutama terhadap aspek KIA. Jenis kepercayaan yang tidak sesuai tersebut sebagian besar terkait aspek gizi selama hamil/bersalin/nifas dan menyusui. Menurut mereka, hal tersebut membuat tubuh mereka gatal karena makan udang atau kerang, akan terjadi perdarahan nifas jika mereka makan ikan. Hal tersebut menyebabkan ibu menjadi banyak pantangan makanan. Padahal, kandungan gizi makanan tersebut sangat bermanfaat bagi ibu dan bayi. Makanan laut seperti kerang dan udang mengandung beberapa zat gizi penting yang merupakan sumber protein hewani dan digolongkan kepada complete protein karena kadar asam amino esensial yang tinggi dan sekitar 85\%-95\% mudah diserap tubuh. Ikan juga merupakan sumber protein tinggi yang sangat dibutuhkan tubuh dan apabila dipantang akan berdampak buruk bagi kesehatan ibu dan janin karena ibu kekurangan asupan protein serta berpengaruh terhadap perkembangan janin atau bayinya. ${ }^{10}$

Masih banyak kebiasaan/tradisi yang berhubungan dengan kesehatan bayi dan anak balita yang tidak sesuai dengan nilai-nilai kesehatan. Kepercayaan tersebut sebagian besar terkait aspek gizi pada bayi dan anak balita atau tidak mendukung ASI eksklusif dan penanganan ke- sehatan pada bayi dan anak balita. Menurut mereka, bayi yang hanya diberi ASI tidak akan kenyang dan akan kekurangan gizi. Mengganti ASI dengan cairan yang tidak bergizi akan berdampak buruk bagi kondisi bayi, daya tahan hidup, pertumbuhan, dan perkembangan. Konsumsi air putih atau cairan lain akan membuat bayi merasa kenyang sehingga tidak mau menyusu. Padahal, ASI kaya dengan gizi yang sempurna untuk bayi. Memberikan air putih sebagai tambahan cairan sebelum bayi berusia 6 bulan dapat mengurangi asupan ASI hingga $11 \%$. Pemberian air manis dalam minggu pertama usia bayi berhubungan dengan penurunan berat badan bayi. ${ }^{11}$

\section{Kesimpulan}

Perilaku responden tentang kehamilan, persalinan, dan nifas yakni dengan kategori pengetahuan baik, kategori sikap netral dan kategori praktek sebagian besar adalah baik. Perilaku responden terhadap kesehatan bayi dan anak balita sebagian besar kategori pengetahuan adalah cukup, sikap sudah berada pada kategori positif, dan praktek pada kategori baik. Orang kunci yang berpengaruh besar terhadap pengambilan keputusan upaya tindakan kesehatan sebagian besar adalah sua$\mathrm{mi} /$ istri. Dilihat dari aspek kecepattanggapan keluarga dalam merespons anggota keluarga yang sakit (bermasalah) terutama terhadap KIA, sebagian besar responden tidak merasa ada keterlambatan dalam memutuskan upaya tindakan kesehatan. Masih banyak kepercayaan masyarakat yang belum sesuai dengan nilai-nilai kesehatan, terutama terhadap aspek KIA.

\section{Saran}

Bagi pemerintah Provinsi Riau khususnya dinas kesehatan diharapkan lebih meningkatkan gerak pembangunan kesehatan khususnya untuk pelayanan KIA karena masih banyak indikator pelayanan KIA yang belum mencapai target. Peningkatan anggaran promosi kesehatan dalam merubah perilaku khususnya untuk daerah pertanian dan pesisir. Bagi tenaga kesehatan diharapkan adanya upaya peningkatan perilaku masyarakat tentang kesehatan melalui program promosi kesehatan/pemberdayaan masyarakat. Masyarakat diharapkan meningkatkan perilaku kesehatan dan kesadaran pentingnya pelayanan kesehatan secara mandiri, seperti di pos kesehatan desa, pondok bersalin desa, dan pos pelayanan terpadu. Pemerintah tidak hanya konsentrasi menjamin pembiayaan kesehatan pada masyarakat miskin. Walaupun secara implementasi mereka dengan kategori penghasilan menengah keatas mampu memenuhi pembiayaan kesehatan tanpa subsidi dari pemerintah, hendaknya mereka ditanamkan supaya ikut dalam kepesertaan asuransi kesehatan secara mandiri (termasuk menghidupkan kembali dana sehat), 
terutama bagi mereka yang berpenghasilan menengah kebawah.

\section{Daftar Pustaka}

1. Departemen Kesehatan RI. Setiap jam, 2 orang ibu bersalin meninggal dunia. 2004 [diakses tanggal 2 Januari 2008]. Diunduh dari: h t t p : / / $202.155 .5 .44 / \mathrm{index} . \mathrm{php}$ ? opt i on = news \& task=viewarticle $\&$ sid $=448 \&$ Itemid $=2$.

2. Dinas Kesehatan Provinsi Riau. Profil kesehatan Provinsi Riau tahun 2007. Riau: Dinas Kesehatan Provinsi Riau; 2007.

3. Zahtamal. Studi/survei MMR-IMR dan indikator-indikator derajat kesehatan tahun 2007. Riau: PT Wastu Asrindoriau; 2007.

4. Arali. Capaian MDG's peningkatan kesehatan ibu di Polewali Mandar. 2008 [diakses tanggal 2 November 2009]. Diunduh dari: http://arali2008.wordpress.com/2009/08/09/capaian-mdgs-peningkatan-kesehatan-ibu-di-polewali-mandar.

5. Dinas Kesehatan Kabupaten Ngawi. Profil kesehatan Kabupaten Ngawi tahun 2008. 2009 [diakses tanggal 2 November 2009]. Diunduh dari: http://www.profilkesngawi2008.html.
6. Notoatmodjo S. Promosi kesehatan: teori dan aplikasi. Jakarta: PT Rineka Cipta; 2005.

7. Azwar S. Sikap manusia, teori, dan pengukurannya. Yogyakarta: Pustaka Pelajar Offset; 2000.

8. Meyske E. Faktor yang berkaitan dengan praktek pemberian asi eksklusif. 2009 [diakses tanggal 2 November 2009]. Diunduh dari: http://www.fkm.unair.ac.id.

9. Musadad A, Rachmalina, Rahajeng E. Pengambilan keputusan dalam pertolongan persalinan di Provinsi Nusa Tenggara Timur. 2003 [diakses tanggal 2 November 2009]. Diunduh dari: http://www.ekologi.litbang.depkes.go.id/data/vol\%202/Anwar2_1.pdf.

10. Anonim. Udang: kaya protein dan rendah kalori. 2007 [diakses tanggal 2 November 2008]. Diunduh dari: http://www.sportindo.com/page/181/Food_Nutrition/Articles_Tips/Udang_Kaya_Protein_dan_Rend ah_Kalori.html.

11. Linkages. Satu-satunya sumber cairan yang dibutuhkan bayi usia dini. 2002 [diakses tanggal 2 November 2009]. Diunduh dari: http://www.linkagesproject.org/media/publications/ENA-References /Indonesia/Ref4.7\%20.pdf. 